\title{
Survey of the levels of some heavy metals in roadside dusts along Katima Mulilo Urban road construction, Namibia
}

\author{
J. Abah ${ }^{1, *}$, P. Mashebe ${ }^{1}$, S. A. Onjefu ${ }^{2}$ \\ ${ }^{1}$ Department of Mathematics, Science and Sport Education, Katima Mulilo Campus, Private Bag, 1096, University of Namibia \\ ${ }^{2}$ Department of Natural Sciences, Namibia University of Science and Technology, Private Bag, 13388, Windhoek, Namibia
}

\section{Email address:}

jabah@unam.na (J. Abah),pmashebe@unam.na (P. Mashebe), sonjefu1@yahoo.com (S. A. Onjefu)

\section{To cite this article:}

J. Abah, P. Mashebe, S. A. Onjefu. Survey of the Levels of some Heavy Metals in Roadside Dusts along Katima Mulilo Urban Road Construction, Namibia. American Journal of Environmental Protection. Vol. 3, No. 1, 2014, pp. 19-27.

doi: 10.11648/j.ajep.20140301.13

\begin{abstract}
Roadside dusts pollutions with heavy metals continue to attract attention as more anthropogenic activities including urban road construction impacted on the natural metal loads of the environment. This study employed analytical procedures to investigate the concentrations of arsenic, lead, chromium, cadmium, cobalt, copper, nickel, manganese, vanadium, iron and tin in the roadside dusts along Katima Mulilo urban road construction. Replicate dusts samples collected from three different areas of the road and a quiet residential area (control) were digested by EPA method 3050B followed by Inductively Coupled Plasma-Optical Emission Spectrophotometer (ICP: Perkin Elmer Optima 7000 DV) analysis. The results of levels of the heavy metals revealed that iron recorded the highest concentration of $7491.13 \pm 0.15 \mathrm{mg} / \mathrm{kg}$ along the road construction while tin recorded the lowest value $(0.27 \pm 0.13 \mathrm{mg} / \mathrm{kg})$. Similar trend was observed at the control area located 1.5 $\mathrm{km}$ away from the road: iron recorded the highest concentration of $2327.17 \pm 0.12 \mathrm{mg} / \mathrm{kg}$ while tin recorded the lowest concentration $(0.20 \pm 0.10 \mathrm{mg} / \mathrm{kg})$. The analysis of variance of the heavy metal concentrations across the sample locations were statistically significant $(\mathrm{p}>0.05)$. However, the levels of the heavy metals recorded cross the sampling areas were less than their soil maximum permissible concentrations. There are strong positive inter-elemental correlations between the sampling areas while result of the soil enrichment factors showed significant enrichment; which are related to common and input from anthropogenically induced sources respectively. The results of single element pollution indexes of the heavy metals showed low contaminations but elevated levels of arsenic and cadmium in all the sampling areas. These could become a potential source of health concern following environmental accumulation and non-biodegradation of the heavy metals. Thus, it is recommended among others that an environmental impact assessment should be carried out on gravel sites to be used in urban road construction to limit heavy metal contaminations of roadside dusts following their usage.
\end{abstract}

Keywords: Urban Road Construction, Heavy Metals, Roadside Dusts, Pollution

\section{Introduction}

The release of heavy metals is one of the most significant environmental problems caused by anthropogenic activities such as urban road construction, quarrying, agriculture, waste incinerations, sewage disposal, automobile workshops, bush burning etc. The presence of heavy metals has been considered as useful indicators for contamination in surface soil, sediment and dust environments [1]. Although, the accumulations of heavy metals on urban surfaces have been attributed to vehicle exhausts, industrial discharges, oil lubricants, automobile parts, corrosion of building materials, atmospheric deposition [2, 3] and particulate emission [4]; import of gravels from quarry sites for urban road constructions represents a significant source of metal contaminations in the urban environment. In roads construction - an important part of urbanization drive; different kinds of gravels are imported from different quarry sites naturally enriched with diverse heavy metals. Thus, there is high potential for increasing the metal loads of the urban soils following this development.

In recent years, there has been growing concern for the potential contribution of ingested dust towards trace metal toxicities in humans. Young children are particularly more likely to ingest significant quantities of dust than adults 
because of the behaviour of mouthing non-food objects and repetitive hand/finger sucking [5]. More worrisome; studies have shown that children have higher absorption rate of trace metals from digestive system and higher hemoglobin sensitivity to trace metals than adults [6]. Consequently, children are more vulnerable to heavy metals toxicities than adults. Elsewhere, some studies have been carried out on street dust near places where children play [7, 8] since children are more sensitive to contaminant-bearing dust [8]. Particulates of smaller sizes are persistent in the environment and exert negative health impact to the exposed resident population, especially in the urban settings [9]. Particle size and chemical composition of dust could decide the significant impact of dust on air quality, public health, and climate [10]. Although, there have been considerable number of studies of heavy metals concentration of street dusts, the vast majority are carried in developed countries with long histories of industrialization [11]. However, the effect of progressive and localised anthropogenic activities on trace metals concentration of environmental indices also need to be evaluated periodically in the developing countries to monitor the trend of the relationship between emission source and concentrations.

Street or urban roadside dusts consist of vehicular exhaust particles, household dust, soil dust, construction dust and aerosols that are carried freely by air and water $[12,13,8]$. Katima Mulilo urban roadside dusts investigation for trace metals contamination is important because the dusts are easily resuspended into the atmosphere and human exposure to the heavy metal contents via inhalation, ingestion and absorption portends potential adverse health effects. Roadside dusts are freely inhaled by those traversing the road and also living within its vicinity. The more the dusts are contaminated with trace metals, the more people become exposed to the health hazards associated with such metals. Thus, due to the growing concern for the potential contribution of ingested dusts towards heavy metal toxicities in humans - with children being more vulnerable; it is quite pertinent to investigate the impact of urban road construction on the heavy metals concentrations of roadside dusts, especially in Katima Mulilo where there is high human activities such petty trades along urban roads. This study provides baseline data of the levels of some heavy metals of environmental and human health importance in roadside dusts along Katima Mulilo urban road. The determination of metal levels in environmental samples: soils and urban roadside dusts is necessary for monitoring environmental pollution since such levels can affect the surrounding ecosystems including bioaccumulation in organisms [14].

\section{Materials and Method}

\subsection{Study Area}

This study focused on Katima Mulilo, the capital of Zambezi Region, Namibia. It is located on latitude $17^{\circ} 30^{\prime} 00^{\prime \prime} \mathrm{S}$ and longitude $24^{\circ} 16^{\prime} 00^{\prime \prime} \mathrm{E}$ based on the World
Geodetic System (WGS) 84 coordinate reference system. Katima Mulilo urban settlement is currently undergoing tremendous road network and other infrastructural transformations characterized with diverse and high human activities. This trend of urbanization has great implication for anthropogenic pollution, especially heavy metal concentrations in environmental indices. According to Namibia 2011 population and housing census preliminary result, Katima Mulilo urban has a population of 28,200 [15] and a total land area of $32 \mathrm{Sq.Km}$. Vehicular traffic congestion is also on the increase and this has been associated with the release of particulates into the environment. Consequently, the monitoring of environmental pollution indicators such as heavy metals becomes necessary to check unintended exposure of the populace.

\subsection{Sample Collection and Pretreatment}

Eight replicate roadside dusts samples were collected on weekly basis during the peak month of dry season in Katima Mulilo between Septembers - October, 2013. On each sampling day, roadside dusts were randomly collected from four points on both sides of the road by sweeping surface dusts into plastic waste packer using plastic brush and then transferred into pre-labelled polyethene bags. Samples were collect between $6 \mathrm{~h} 00$ and $8 \mathrm{~h} 00$ to allow dust emitted into the atmosphere during the day to settle. The samples were collected along Pick n Pay - Standard bank, Cash n Cary - Kamunu shopping mall, and old National Housing Enterprise urban roads construction in katima Mulilo metropolis. Control samples were similarly collected in quite residential areas along Malena Street. The selected control sites were located $1.5 \mathrm{~km}$ from the road and are areas devoid of the current anthropogenic activities along the urban road construction.

The roadside dusts samples consisted of a variety of dust particle sizes ranging from large grit to aerosol particles. All irrelevant materials like cigarette ends, fallen dry leaf, pebbles etc were first carefully hand-picked and the dusts exposed to air-drying under atmospheric temperature for five days. Thereafter, samples collected at each location were ground together thoroughly to ensure homogeneity and filtered through $75 \mu \mathrm{m}$ stainless steel sieve. This sieve fraction was selected because it has been reported that dust particles ranging from 75-125 $\mu \mathrm{m}$ contain high levels of heavy metals and are known to be the very harmful to humans if inhaled [16, 17]. Three sub-samples were taken from the large sieved samples and transferred into clean, pre-labelled polyethylene bags and then conveyed to Analytical Laboratory Services, Windhoek Namibia, for further processing and analyses. All materials used for holding samples, homogenization and sieving were precleaned to minimize the potential of cross contamination.

\subsection{Sample Digestion}

The dust samples were digested according to EPA method 3050B for Inductively Coupled Plasma-Optical 
Emission Spectrophotometer (ICP-OES) analysis. A known amount $(1.00 \mathrm{~g})$ of each sieved dust was transferred into a digestion vessel and $10 \mathrm{~mL}$ of $1: 1$ nitric acid $\left(\mathrm{HNO}_{3}\right)$ was added, mixed thoroughly and covered with a watch glass. Then, the samples were heated to $90^{\circ} \mathrm{C}$ and refluxed at this temperature for 10 minutes after which they were allowed to cool for 5 minutes under room temperature. Thereafter, 5 $\mathrm{mL}$ of concentrated $\mathrm{HNO}_{3}$ was added to each, covered and refluxed again at $90^{\circ} \mathrm{C}$ for 30 minutes. Then, the solutions were allowed to evaporate without boiling to approximately $5 \mathrm{~mL}$ each and cooled again for 5 minutes. This was followed by the addition of $2 \mathrm{~mL}$ of deionised water plus 3 $\mathrm{mL}$ of $30 \%$ hydrogen peroxide $\left(\mathrm{H}_{2} \mathrm{O}_{2}\right)$ to each. The vessels were covered and heated just enough to warm the solutions for the peroxide reaction to start [18]. This was continued until effervescence subsided and the solutions were cooled.

The acid-peroxide digestates were covered with watch glasses and heated until the volume reduced to approximately $5 \mathrm{~mL}$ again. Then, $10 \mathrm{~mL}$ of concentrated hydrochloric acid $(\mathrm{HCl})$ was added to each, covered and heated on a heating mantle, then refluxed at $90^{\circ} \mathrm{C}$ for 15 minutes. After cooling, each digestate was filtered through Whatman No. 41 filter paper into a $100 \mathrm{~mL}$ volumetric flask and the volume made up to the mark with deionised water [18].

\subsection{Sample Analysis}

Ten (10) $\mathrm{mL}$ of each digestate was taken and mixed with equal volume of matrix modifier [18] and then analyzed using ICP-OES (ICP: Perkin Elmer Optima 7000 DV) for the levels of lead, arsenic, chromium, cobalt, nickel, cadmium, copper, vanadium, manganese, iron and tin.

\subsection{Data Analysis}

Data generated from triplicate analyses were subjected to treatment of mean and standard deviation, inter-elemental correlations as well as analysis of variance and t-test at $\mathrm{P}>$ 0.05 error protection to determine the significance of data variation between sample locations.

\subsection{Assessment of Site Contamination}

Topsoil geochemical quality in urban environment depends not only on the concentration of pollution sources, but also on time-span of urbanization and density of the population. It is expedient to compare heavy metal concentrations in the topsoil with their guideline limit values upon which informed decision about the site quality could be made. Depending on the type of use, soil composition needs to fall within given limits. In this study, site contamination was assessed using the criteria of Single Element Pollution Index (SEPI), Combined Pollution Index (CPI), [19], and soil Enrichment Factor (EF), [20]. Each of these assessment criteria was calculated using the following equations.

$$
\begin{aligned}
& \text { SEPI }=\frac{\text { Soil metal concentration }}{\text { Soil permiszible li mit of the metal }} \\
& \text { CPI }=\frac{\text { Soil metal concentration/Its Soil pMC }}{\text { Number of the merals invertigared }} \\
& \text { EF }=\frac{C / \text { Fe(zample) }}{C / F \text { (earth cruat) }}
\end{aligned}
$$

Where PMC is the permissible maximum concentration used [21], $\mathrm{C} / \mathrm{Fe}$ (sample) is the ratio of the metal to $\mathrm{Fe}$ concentration of the sample and $\mathrm{C} / \mathrm{Fe}$ (earth crust) is the ratio of the metal to Fe concentration of the earth crust. The earth's crust $\mathrm{Fe}$ concentration used in this study was the value reported in the "Nature's building blocks: an A-Z guide to the element" [22].

\section{Results and Discussion}

\subsection{Concentrations of the Heavy Metals in the Roadside Soils}

Table 1 presents the concentrations $(\mathrm{mg} / \mathrm{kg})$ of some heavy metals (arsenic (As), lead $(\mathrm{Pb})$, chromium $(\mathrm{Cr})$ cadmium $(\mathrm{Cd})$, cobalt $(\mathrm{Co})$, copper $(\mathrm{Cu})$, nickel $(\mathrm{Ni})$, manganese $(\mathrm{Mn})$, iron $(\mathrm{Fe})$, vanadium $(\mathrm{V})$ and tin $(\mathrm{Sn}))$ determined in the roadside dusts along Katima Mulilo urban road construction and a residential area as control. The levels of the heavy metals showed wide variations; iron $(\mathrm{Fe})$ recorded the highest concentrations among the metals with a level of $7491.13 \pm 0.15 \mathrm{mg} / \mathrm{kg}$ at Pick $\mathrm{n}$ pay Standard bank axis of the road construction while a record of $2327.17 \pm 0.12 \mathrm{mg} / \mathrm{kg}$ was obtained at the residential area located $1.5 \mathrm{~km}$ away from the road. Sn recorded the lowest concentration with a record of $0.27 \pm 0.13 \mathrm{mg} / \mathrm{kg}$ at the old National Housing Enterprise (NHE) part of the road construction while $0.20 \pm 0.10 \mathrm{mg} / \mathrm{kg}$ was recorded at the control area. The results of the analysis of variance of the heavy metal concentrations across the sample locations were statistically significant $(p>0.05)$. This may be attributed to the variation in intensities of anthropogenic activities at each sampling area. The concentrations of the heavy metals at Pick n pay - Standard bank axis, Cash $n$ carry - Kamunu shopping mall axis and the old NHE route where there were high anthropogenic activities due to urban road constructions were higher than the results obtained at the residential area of Malena street sampled as control. However, the levels of the heavy metals recorded cross the sampling areas were less than their soil maximum permissible concentrations (Appendix 1) [21].

The overall mean concentrations of the heavy metals across the study area (Fig. 1) indicated significantly higher levels along the road construction than the residential area. This has significant implication for the metal inputs from the construction works and other anthropogenic activities along the urban road. The import of gravels from rock sites previously enriched with diverse metal elements no doubt contributed immensely to the elevated heavy metal 
concentrations recorded in the roadside dusts. Furthermore, heavy trucks and machineries used at the construction site are important factors to the increased metals load of the roadside dusts due to burning of heavy duty oils, wear and tear of brake pads and tires which released particulates that are subsequently deposited on to the surface soil. Roads generally have been identified as the second largest nonpoint source of pollution in urban environment [23]. Traffic congestions associated with high rates of stop and starts of motor vehicles have been reported to increase heavy metals concentrations of roadside soil. In the first few minutes of a motor vehicle engine being engaged, the largest source of catalytic converter particulates are being deposited onto the road surface during which several heavy metals are released [16]. In a similar study elsewhere in the Hilla city of Iraqi, high contents of metal elements in roadside dusts were also attributed to anthropogenic effects related to traffic sources [24]. The stop and start pattern of motor vehicles are very high occurrence along the Katima Mulilo urban road construction, and this situation was further aggravated by the narrowness of the road.

Table 1. Concentrations ( $\mathrm{mg} / \mathrm{kg}$ ) of some heavy metals along Katima Mulilo urban road construction and residential area (control)

\begin{tabular}{|c|c|c|c|c|}
\hline Heavy metal & PnP - StB & CnC - K mall & Old NHE & $\mathbf{R A}$ \\
\hline As & $5.10^{\mathrm{a}} \pm 0.20$ & $2.50^{\mathrm{b}} \pm 0.20$ & $4.77^{c} \pm 0.52$ & $2.30^{\mathrm{d}} \pm 0.10$ \\
\hline $\mathrm{Pb}$ & $2.37^{\mathrm{a}} \pm 0.12$ & $2.26^{\mathrm{b}} \pm 0.52$ & $2.17^{\mathrm{c}} \pm 0.21$ & $1.57^{\mathrm{d}} \pm 0.18$ \\
\hline $\mathrm{Cr}$ & $5.60^{\mathrm{a}} \pm 0.10$ & $3.70^{\mathrm{b}} \pm 0.10$ & $4.13^{c} \pm 0.15$ & $2.10^{\mathrm{d}} \pm 0.10$ \\
\hline $\mathrm{Cd}$ & $1.23^{\mathrm{a}} \pm 0.06$ & $0.93^{b} \pm 0.15$ & $0.87^{\mathrm{c}} \pm 0.13$ & $0.40^{\mathrm{d}} \pm 0.13$ \\
\hline Co & $3.20^{\mathrm{a}} \pm 0.17$ & $2.47^{\mathrm{b}} \pm 0.50$ & $2.43^{\mathrm{c}} \pm 0.15$ & $0.87^{\mathrm{d}} \pm 0.13$ \\
\hline $\mathrm{Cu}$ & $16.07^{\mathrm{a}} \pm 0.21$ & $15.47^{b} \pm 0.65$ & $8.40^{\mathrm{c}} \pm 0.17$ & $4.57^{\mathrm{d}} \pm 0.50$ \\
\hline $\mathrm{Ni}$ & $5.83^{\mathrm{a}} \pm 0.15$ & $5.07^{b} \pm 0.12$ & $4.80^{\mathrm{c}} \pm 0.17$ & $2.17^{\mathrm{d}} \pm 0.12$ \\
\hline $\mathrm{Mn}$ & $108.10^{\mathrm{a}} \pm 0.10$ & $85.3^{\mathrm{b}} \pm 0.10$ & $73.57^{\mathrm{c}} \pm 0.12$ & $37.40^{\mathrm{d}} \pm 0.53$ \\
\hline $\mathrm{Fe}$ & $7491.13^{\mathrm{a}} \pm 0.15$ & $6575.17^{\mathrm{b}} \pm 0.29$ & $4376.60^{c} \pm 0.20$ & $2327.17^{\mathrm{d}} \pm 0.12$ \\
\hline V & $19.27^{\mathrm{a}} \pm 0.23$ & $12.33^{\mathrm{b}} \pm 0.15$ & $11.23^{\mathrm{c}} \pm 0.12$ & $5.63^{\mathrm{d}} \pm 0.15$ \\
\hline $\mathrm{Sn}$ & $0.40^{\mathrm{a}} \pm 0.10$ & $0.37^{\mathrm{b}} \pm 0.18$ & $0.27^{\mathrm{c}} \pm 0.13$ & $0.20^{\mathrm{d}} \pm 0.10$ \\
\hline
\end{tabular}

Within rows, data with different alphabets are significantly different at $\mathrm{p}>0.05$. Data presented are mean \pm standard deviation of triplicate analyses Key: PnP $-\mathrm{StdB}=$ Pick $\mathrm{n}$ pay - Standard bank axis, $\mathrm{CnC}-\mathrm{K}=$ Cash $\mathrm{n}$ carry - Kamunu shopping mall, NHE $=\mathrm{National}$ housing enterprise, $\mathrm{RA}=$ Residential area

Table 2. Contamination categories based on Single Element Pollution Index (SEPI) [19] and soil Enrichment Factor (EF) [20]

\begin{tabular}{|c|c|c|c|}
\hline \multicolumn{2}{|c|}{ Single Element Pollution Index } & \multicolumn{2}{|c|}{ Enrichment Factor } \\
\hline Classification & Degree of contamination & Classification & Degree of enrichment \\
\hline $\mathrm{SEPI} \leq 1$ & Low & $\mathrm{EF}<2$ & Deficient to minimal \\
\hline $1<\mathrm{SEPI} \leq 3$ & Moderate & $2<\mathrm{EF}<5$ & Moderate \\
\hline \multirow[t]{3}{*}{$\mathrm{SEPI}>3$} & High & $5<\mathrm{EF}<20$ & Significant \\
\hline & & $20<\mathrm{EF}<40$ & Very high \\
\hline & & $\mathrm{EF}>40$ & Extremely high \\
\hline
\end{tabular}

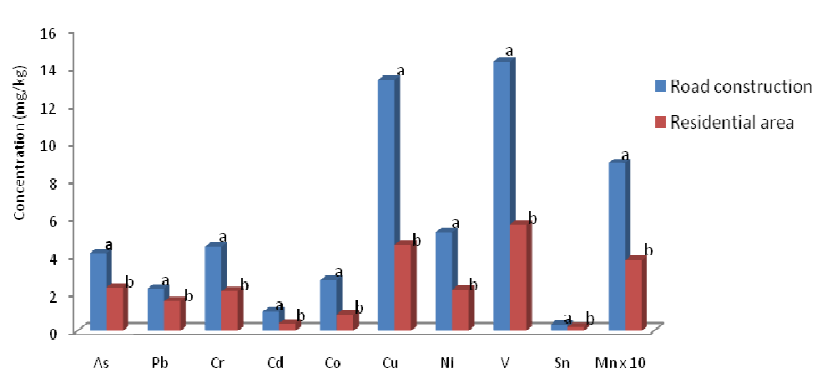

Figure 1. Overall mean concentrations $(\mathrm{mg} / \mathrm{kg})$ of the heavy metals at the study area Different alphabets on bars indicate significant variations ( $p>$ 0.05) between sample locations

The relative mean concentrations of iron across the study area (Fig. 2) also indicated significantly higher levels at the areas where urban road construction is in progress compared to the residential area sampled as control. Although, iron concentration was determined because of its choice as the element of normalization to determine the soil enrichment factors, the obvious elevated levels along the road construction has implication for anthropogenically induced sources.

\subsection{Pollution Indexes}

The Single Element Pollution Indexes (SEPI) of the heavy metals across the study area (Fig. 3) indicated elevated levels of arsenic and cadmium. Generally, the ranges of the pollution indexes of the heavy metals $(0.022-0.510$ and $0.020-0.230)$ along the urban road construction and residential area (control) respectively, revealed low 
contamination (SEPI $\leq 1)$ as classified in Table 2 using established guideline [19]. However, some of the heavy metals (e.g $\mathrm{Pb}, \mathrm{Cr}, \mathrm{Cd}$ ) have been identified among the toxic elements that will continue to accumulate in urban environment due to their non-biodegradability and long residence time. Many heavy metals accumulate in one or more of the body organs with differing half-lives. These metals apart from acute or chronic poisoning can be transferred to next generation with potential toxicity from the viewpoint of public health [25]. Human exposures to trace metal elements have been noted with great concern, particularly because of the classification of some (e.g, As, $\mathrm{Cd}, \mathrm{Cr}, \mathrm{Ni}$ ) as potential carcinogens. Carcinogenic substances are those that induce tumors (benign or malignant), increase their incidence or malignancy or shorten the time of tumor occurrence when they get into the body through inhalation, injection, dermal application or ingestion [26]. Prolonged exposure to $\mathrm{Cd}$ can affect a variety of organs with the kidney being the principal target [24]. It was also reported that populations exposed to $\mathrm{Cd}$, $\mathrm{Cu}$, and $\mathrm{Zn}$ pollutants are at risk of developing nervous system alterations which can lead to health hazards [27].

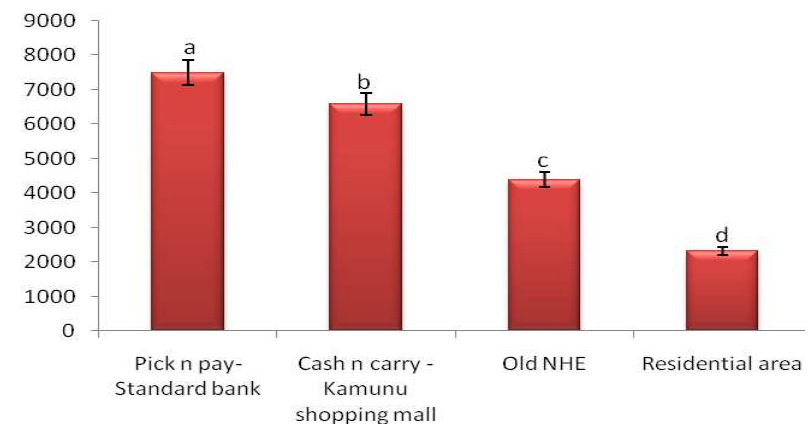

Figure 2. Relative mean concentrations $(\mathrm{mg} / \mathrm{kg})$ of iron at the study area Different alphabets on bars indicate significant variations $(p>0.05)$ between sample locations

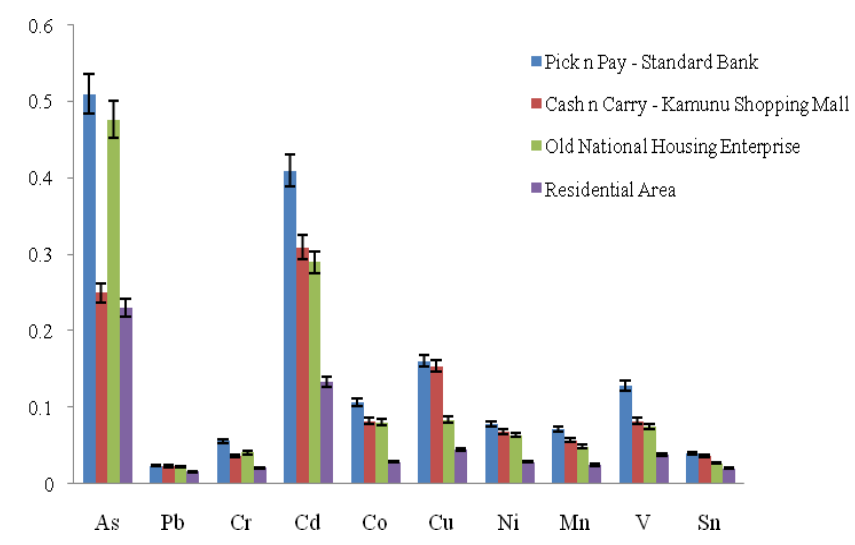

Figure 3. Single pollution indexes of the heavy metals at the study sites

$\mathrm{Cd}$ is a widespread environmental and industrial pollutant, which has been declared carcinogen by International Agency for Cancer Research [28].

Chronic exposure to inorganic arsenic have been associated with various health effects such as irritation of the stomach and intestines, decreased production of red and white blood cells, skin changes and lung irritation [29]. It was also reported that absorption of significant amounts of inorganic arsenic can increase the chances of cancer development, especially skin cancer, lung cancer and liver cancer. Other cancers liked to arsenic toxicity include kidney and bladder [30]. The toxicity of arsenic and its inorganic compounds has been classified as: acute toxicity, sub-chronic toxicity, genetic toxicity, developmental and reproductive toxicity [31], immunotoxicity [32], biochemical and cellular toxicity [33]. It has also been reported that arsenic-induced oxidative stress causes DNA strand breaks; an alkali-labile sites which eventually results into DNA adducts [34]. Report also indicated that arsenic mediation can alter methylation status of oncogenes and tumor suppressor genes and in the processes enhancing carcinogenesis [35].

Single element pollution indexes of $\mathrm{Co}, \mathrm{Cu}$ and $\mathrm{V}$ also revealed potential area of concern due to the possibility of their geo-accumulation in the environment. The International Agency for Research on Cancer (IARC) has listed cobalt and cobalt compounds within group 2B (agents which are possibly carcinogenic to humans). Humans with implants of cobalt containing prostheses are reported to be at increased risk of sarcomas and blood neoplasm. Occupational exposure epidemiological studies also reported increased risk of lung cancer in humans [36]. Exposures to high concentration of copper may cause metal fume fever in which symptoms may include metallic taste in the mouth, dryness and irritation of the throat, cough, feeling of weakness, fatigue with fever, chills and profuse sweating. It was also reported that excessive exposure to vanadium may result in irritation of the respiratory tract and conjunctivae, skin pallor, greenish discoloration of the tongue, eczematous skin lesions, cough, bronchitis and chest pains. Long term exposure may cause pulmonary edema, pneumonia, chronic bronchitis, anemia, albuminuria and nervous complaints.

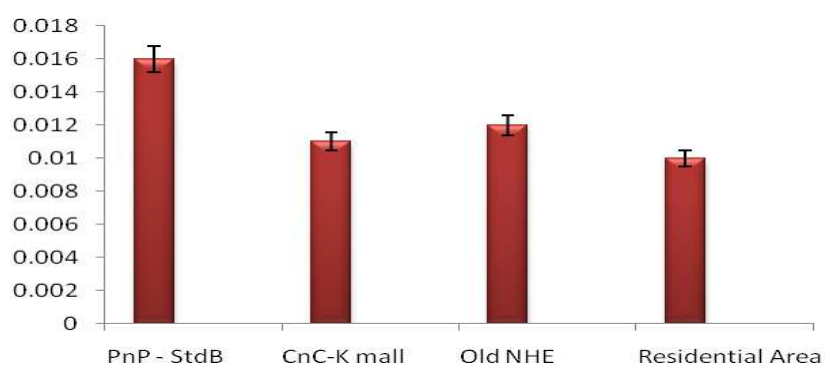

Figure 4. Combined pollution index of the heavy metals at the study sites Key: PnP $-\mathrm{StdB}=$ Pick n pay - Standard bank axis, $\mathrm{CnC}-\mathrm{K}=$ Cash $\mathrm{n}$ carry - Kamunu shopping mall, $\mathrm{NHE}=$ National housing enterprise

The Combined Pollution Index (CPI) of the heavy metals at each location (Fig. 4) was less than one (1) which indicates that average levels of the metals are below the selected standards but does not necessarily indicate that there are no anthropogenic sources of enrichment over background level, and suggested single metal 
contamination [37]. The trend of the CPI revealed that Pick $\mathrm{n}$ pay - Standard bank axis $>$ old NHE $>$ Cash n carry Kamunu shopping mall $>$ residential area (control). This trend suggested that the locations along the urban road construction received more heavy metals input from anthropogenically induced sources.

Table 3. Enrichment factors of the heavy metals metals at the study sites

\begin{tabular}{|c|c|c|c|c|}
\hline Heavy metal & PnP - StdB & CnC-K mall & Old NHE & RA \\
\hline As & 5.67 & 6.33 & 9.08 & 16.50 \\
\hline $\mathrm{Pb}$ & 5.33 & 5.67 & 10.00 & 16.75 \\
\hline $\mathrm{Cr}$ & 5.36 & 6.22 & 9.40 & 18.00 \\
\hline $\mathrm{Cd}$ & 5.33 & 7.00 & 10.00 & 17.00 \\
\hline $\mathrm{Co}$ & 5.38 & 6.33 & 11.20 & 18.50 \\
\hline $\mathrm{Cu}$ & 5.51 & 6.18 & 9.60 & 17.82 \\
\hline $\mathrm{Ni}$ & 5.57 & 6.42 & 9.16 & 18.60 \\
\hline $\mathrm{Mn}$ & 5.47 & 6.24 & 9.39 & 17.66 \\
\hline V & 5.47 & 6.27 & 9.52 & 14.24 \\
\hline $\mathrm{Sn}$ & 5.00 & 6.00 & 6.00 & 17.53 \\
\hline
\end{tabular}

Key: PnP - StdB $=$ Pick n pay - Standard bank axis, $\mathrm{CnC}-\mathrm{K}=$ Cash $\mathrm{n}$ carry - Kamunu shopping mall, NHE $=$ National housing enterprise, $\mathrm{RA}=$ Residential area

Table 4. Inter-elemental correlation analysis of the sampling points

\begin{tabular}{|c|c|c|c|c|c|c|c|c|c|c|}
\hline & As & $\mathbf{P b}$ & $\mathrm{Cr}$ & Cd & Co & $\mathbf{C u}$ & $\mathrm{Ni}$ & Mn & $\mathbf{V}$ & Sn \\
\hline As & 1.0000 & & & & & & & & & \\
\hline $\mathrm{Pb}$ & 0.7236 & 1.0000 & & & & & & & & \\
\hline $\mathrm{Cr}$ & 0.8466 & 0.9441 & 1.0000 & & & & & & & \\
\hline $\mathrm{Cd}$ & 0.7180 & 0.9784 & 0.9745 & 1.0000 & & & & & & \\
\hline $\mathrm{Cu}$ & $0.3229 *$ & 0.8475 & 0.7748 & 0.8899 & 0.8637 & 1.0000 & & & & \\
\hline $\mathrm{Ni}$ & 0.6763 & 0.9976 & 0.9313 & 0.9796 & 0.9936 & 0.8804 & 1.0000 & & & \\
\hline $\mathrm{Mn}$ & 0.6540 & 0.9657 & 0.9540 & 0.9958 & 0.9829 & 0.9271 & 0.9732 & 1.0000 & & \\
\hline V & 0.7235 & 0.9145 & 0.9751 & 0.9775 & 0.9486 & 0.8651 & 0.9151 & 0.9765 & 1.0000 & \\
\hline $\mathrm{Sn}$ & $0.4066^{*}$ & 0.8784 & 0.8296 & 0.9256 & 0.8984 & 0.9954 & 0.9058 & 0.9563 & 0.9093 & 1.0000 \\
\hline
\end{tabular}

Data with asterisk $(*)$ showed less correlations between paired metals

\subsection{Soil Enrichment Factors}

The enrichment factors of the heavy metals at the study sites (Table 3) showed that along Pick n pay - Standard bank axis, the result varied between 5.00 to 5.67 while along Cash n carry - Kamunu shopping mall axis, a record varying between 6.00 to 7.00 was obtained. At old National Housing Enterprise road construction, the soil enrichment factor ranged from 6.00 to 11.20 while the result in the residential area showed a record of 14.24 to 18.60 . The current values of the roadside dusts enrichment factors of the heavy metals indicated that the areas have significant enrichment $(5<\mathrm{EF}<20)$ as classified in Table 2 above using established guideline [20]. This level of soil heavy metals enrichment is related to input from anthropogenically induced sources. The concept of enrichment factor was used in this study to assess the level of contamination and the possible anthropogenic impact along Katima Mulilo urban road construction. Comparisons were made to background concentrations in the earth's crust using $\mathrm{Fe}$ as reference element following the assumption that its' content in the crust has not been disturbed by anthropogenic activities, and it has been chosen as the element of normalization because natural sources (98\%) vastly dominate its input [38]. Furthermore, iron was proposed as an acceptable normalization element in the calculation of enrichment factors since its distribution was not related to other heavy metals [39]. In this study, iron concentration was indeed far higher than the level obtained for any of the other metals.

\subsection{Correlation Analysis of the Heavy Metals Concentration}

The result of inter-elemental correlation analyses (Table 4) indicated that apart from $\mathrm{Cu}$ and $\mathrm{Sn}$ which showed less correlation with As, all the other metals showed strong positive correlation across the sampling areas. This 
suggested common source of anthropogenic input across the study area. The trend of this inter-elemental correlation reflects the possible aerial deposition of dusts emitted from the urban road construction sites onto the residential area, thus transferring adhered trace metal contaminants. It has been reported that trans-boundary air pollution is a major source of exposure to heavy metals and because of their persistence and potential for global atmospheric transfer; pollutants emitted into the atmosphere from a particular source could affect even the most remote areas [1]. A major challenge for the identification of background concentrations in urban geochemical studies is the fact that urban soils are typically disturbed by human activities or imported into the city from surrounding areas, and may not exhibit the natural stratification found in the undisturbed areas [40]. Thus, environmental pollutants such as heavy metals will continue to play important role as their concentrations in soil, water and air are significantly increasing due to anthropogenic activities.

\section{Conclusion}

The results of this study revealed significant presence of arsenic, lead, chromium, cadmium, cobalt, copper, nickel, manganese, vanadium, iron and tin in the roadside dusts along Katima Mulilo urban road construction. Although, the results obtained showed lower levels than the reported soil maximum permissible concentrations of the heavy metals; accumulations in the environment is possible and people traversing the road as well as living within its vicinity are exposed to this potentially contaminant-bearing dusts via inhalation, dermal contact, ingestion and absorption. Furthermore, the upsurge of petty trades along the road construction also present another exposure route with children being more vulnerable because of their reported higher absorption rate of trace metals and higher hemoglobin sensitivity than adults. The single element pollution index of the heavy metals showed elevated levels of arsenic and cadmium in all the sampling areas and this may become a great source of concern following accumulation in the environment; more also, that these elements are classified as potential human carcinogens. All the heavy metals are positively correlated which suggested common source of anthropogenic contamination. Furthermore, the values of enrichment factors in the roadside dusts indicated significant enrichment, which is also related to input from anthropogenically induced sources. Thus, it is recommended that environmental impact assessment should be carried out on gravel sites to be used in urban road construction to lower heavy metal contaminations of roadside dusts following their usage. Furthermore, petty trades along urban road construction should be discouraged by government policy to limit prolong exposure to contaminant bearing-dusts during road construction or it should be made incumbent on the contractor to immediately suppress dusts emission with water spraying after laying the gravel prior to asphalting.

\section{Acknowledgements}

We greatly acknowledged the financial support of the University of Namibia, Katima Mulilo Campus to undertake this study. We are also grateful to the Katima Mulilo Urban Council for the approval granted us to collect the roadside dusts samples. We are also thankful to $\mathrm{Mr}$. M.L. Ntabi, Mrs. C. Sibuku and Mr. D.D. Denuga of the University of Namibia, Katima Mulilo Campus for their logistic supports that facilitated the sample collections. Finally, we thank the technologists of Analytical Services Laboratory, Windhoek Namibia for the conducive analytical conditions provided for the laboratory preparations and analysis. God bless.

\section{Appendix 1.}

Maximum Permissible Concentrations (MPC) of the heavy metals in soil [19]

\begin{tabular}{ccc}
\hline Heavy metal & CAS. No & MPC $(\mathbf{m g} / \mathbf{k g})$ \\
\hline $\mathrm{Pb}$ & $7439-92-1$ & 100 \\
$\mathrm{Mn}$ & $7439-92-1$ & 1500 \\
$\mathrm{Ni}$ & $7440-02-0$ & 75 \\
$\mathrm{Sn}$ & $7440-31-5$ & 10 \\
$\mathrm{As}$ & $7440-38-2$ & 10 \\
$\mathrm{Cd}$ & $7440-43-9$ & 3 \\
$\mathrm{Cr}$ & $7440-47-3$ & 100 \\
$\mathrm{Co}$ & $7440-48-4$ & 30 \\
$\mathrm{~V}$ & $7440-62-2$ & 150 \\
$\mathrm{Cu}$ & $7470-50-8$ & 100 \\
\hline
\end{tabular}

\section{References}

[1] S.T. Ubwa, J. Abah, C.A. Ada, and E. Alechenu, E. "Levels of some heavy metals contamination of street dust in the industrial and high traffic density areas of Jos Metropolis", Journal of Biodiversity and Environmental Sciences, Vol. 3: Issue 7; 2013, pp 13-21.

[2] D.C. Adriano, Trace elements in terrestrial environments: biogeochemistry, bioavailability and risks of metals, (2nd ed). Springer, New York, 2001, p. 867.

[3] X. Li, C. Poon and P. Liu, "Heavy metal contamination of urban soils and street dusts in Hong Kong". Appl. Geochem., Vol. 16, 2001. pp 1361-1368. http://dx.doi.org/10.1016/S0883-2927(01)00045-2.

[4] R.A. Sutherland and C.A. Tolosa, "Multi-element analysis of road deposited sediment in an urban drainag basin, Honolulu, Hawaii”. Environmental Pollution, Vol. 110: 2000, pp 483-495. http://dx.doi.org/10.1016/S02697491(99)00311-5.

[5] R. Bargagli, Trace Elements in Terrestrial Plants: an Ecophysiological Approach to Biomonitoring and Biorecovery. Springer- Verlag, Berlin, Germany, 1998. 
[6] P.C. Hammond, Metabolism of lead. In: Chisolm, J. J. O'Hara, D. M. (Eds.), Lead Absoption in Children: Management, Clinical, and Environmental Aspects. Urban and Schwarzenberg, Baltimore Munich, 1982.

[7] S.L. Ng, L.S. Chan, K.C. Lam and W.K. Chan, "Heavy metal contents and magnetic properties of playground dust in Hong Kong", Environmental Monitoring and Assessment. Vol. 89: 2003, pp 221-232.

[8] D. Meza-Figueroa, M. De La O-Villanueva and M.L. De La Parra, "Heavy metal distribution in dust from elementary schools in Hermosillo, Sonora, Mexico", Atmospheric Environment. Vol. 41: 2007, pp 276-288. http://dx.doi.org/10.1016/j.atmosenv.2006.08.034

[9] P.L. Kinney and M. Lippmann, "Respiratory effects of seasonal exposures to ozone and particles", Arch. Environ. Health, Vol. 55, 2000, pp 210-216.

[10] H. Maring, D.L. Savoie, M.A. Izaguirre, L. Custals and J.S. Reid, "Mineral dust aerosol size distribution change during atmospheric transport", Journal of Geophysics Research. Vol. 108: Issue 19, 2003, 85-92. http://dx.doi/10.1029/2002JD002536.

[11] O.M. Jaradat, A.K. Momani, "Contamination of road side soil, plants and air with Heavy metals in Jordan, A Comparative study", Turk. J. Chem. Vol. 23: 1999, pp 209220.

[12] H. Takada, T. Honda, M. Harada and N. Ogura, "Distribution and sources of polycyclic aromatic hydrocarbons (PAHs) in street dust from the Tokyo Metropolitan area", Science of Total Environment. Vol. 107: 1991, pp 45-69. http://dx.doi.org/10.1016/00489697(91)90249-E

[13] O.A. Al- Khashman, "Heavy metal distribution in dust, street dust and soils from the work place in Karak Industrial Estate, Jordan", Atmospheric Environment. Vol. 38: 2004, $\mathrm{pp}$ 6803-6812. http://dx.doi.org/10.1016/j.atmosenv.2004.09.011

[14] A. Aksoy and D. Demirezen, "Fraxinus excelsior as a biomonitor of heavy metal Pollution", Polish Journal of Environmental Studies. Vol. 15: 2006, pp 27-33.

[15] NPC, Namibia 2011 population and housing census preliminary results. www.gov.na/documrnts/.../0ea026d4 9687-4851-a693-1b97a1317c60, (2012). Acessed; 7/12/2013.

[16] N.I. Ward, A. Dudding and M. Lyndon, "Platinum emissions and levels in motorway dust samples: influence of traffic characteristics", Science of the Total Environment, Vol. 334335: 2004, pp 457-463.

[17] C. Ewan, M.A. Anagnostopoulou and N.I. Ward, Monitoring of heavy metal levels in roadside dusts of Thessaloniki, Greece in relation to motor vehicle traffic density and flow. epubs.surrey.ac.uk/.../Monitoring_of_Heavy_Metal_Levels_ in_Roadside..., 2009, Accessed; 10/09/2013.

[18] EPA, Method 3050B, acid digestion of sediments, sludge, and soils. 1996, pp 1-12.

[19] T.B Chen, Y.M. Zheng, M. Lei, Z.C. Huang, H.T. Wu, H. Chen, K.K. Fan, K. Yu, X. Wu and Q.Z. Tian, "Assessment of heavy metal pollution in surface soils of urban parks in Beijing, China”, Chemosphere. Vol. 60: Issue 4, 2005, pp
542-551. http://dx.doi:10.1016/j.chemosphere.2004.12.072.

[20] R. Foley, T. Bell and D.G.E. Liverman, "Urban Geochemical Hazard Mapping of St. John's, Newfoundland, Canada", Atlantic Geology Vol. 47: 2011, pp 138-157. http://dx.doi.org/10.4138/atlgeol.2011.007

[21] V. Gregorauskiene, Overview of the quality criteria for soil in the eastern European countries, proceedings of the conference; the abiotic environment - evaluation of changes and hazards- case studies, Polish geological institute special paper, Vol. 24: 2008, pp 45-54.

[22] J. Emsley, Nature's building blocks: an A-Z guide to the elements, Oxford University press, 2001, pp 240-242

[23] S.O. Fakayode and B.I. Olu-Owolabi, "Heavy metalcontamination of roadside topsoil in Osogbo, Nigeria: its relationship to traffic density and proximity to highways", Environ. Geol. Vol. 44: Issue 2, 2003, pp 150-157. http://dx.doi:10.1007/s00254-002-0739-0.

[24] Suad Mahdi Glewa Al-Fatlawi and Mustafa Al-Alwani, "Heavy metal pollution of roadside dust Samples with different traffic volumes at Hilla city", The Iraqi Journal For Mechanical And Material Engineerin. Vol.12: Issue 4, 2012, pp 660-672.

[25] V. Rajaganapathy, F. Xavier, D. Sreekumar and P.K. Mandal, "Heavy metal contamination in soil, water and fodder and their presence in livestock and products : a review", Journal of environmental science and technology, Vol. 4: 2011, pp 234-249. http://dx.doi:10.3923/jest. 2011.234.249.

[26] D. Maurici, M. Aardema, R. Corvi, M. Kleber, C. Krul, C. Laurent, N. Loprieno, M. Pasanen, S. Pfuhler, B. Philips, E. Sabbioni, T. Sanner and P. Vanparys, "Genotoxicity and mutagenicity", Altern Lab Anim. Vol. 33: Issue1, 2005, pp $177-182$.

[27] U.S. EPA, (US Environment Protection Agency), Air quality criteria for mercury and lead. EPA, research triangle park, NC, 1986

[28] International Agency for Research on Cancer (IARC), Monographs on the evaluation of carcinogenic risks to humans, IARC, Lyon, Vol. 1-58: 1993, pp 1972-1993.

[29] Lentech, Arsenic (As)- chemical properties, health and environmental effects. www.lenntech.com > periodic table > elements, Accessed; 23/12/2013.

[30] Agency for Toxic Substance and Disease registry (ATSDR), Toxicological profile for arsenic. U.S. department of health and human services, public health and humans services, center for disease control, Atlanta, 2003.

[31] D. Chakraborti, M.K. Sengupta, M.M. Rahaman, U.K. Amides-Chowdhury and M.A. Hossain, "Ground water arsenic contamination and its health effects in the GangaMegna-Brahmaputra Plain", J Environ Monit. Vol. 6: 2004, pp. 74-83. http://dx.doi: 10.1039/b406573p.

[32] T. Sakurai, C. Kojima, T. Ohta and K. Fujiwara, "Evaluation of in-vivo acute immunotoxicity of major organic arsenic compound arsenobetaine in seafood", Int Immunopharmacol, Vol. 4: 2004, pp 179-184. http://dx.doi: 10.1016/j.intimp.2003.11.004.

[33] A. Mudhoo, S.K. Sharma, V.K. Garg and T.H. Tseng, "Arsenic: an overview of applications, health and 
environmental concerns and removal process", Crit Rev Environ Sci Technol. Vol. 41: 2001, pp 435-519. http://dx.doi: 10.1080/10643380902945771.

[34] Y.S. Pu, K.Y. Jan, T.C. Wang, A.S. Wang and J.R. Gurr, J.R. Y.S. Pu, K.Y. Jan, Wang, T.C., et al. (2007). 8-Oxoguanine DNA glycosylase and MutY homolog are involved in the incision of arsenite-induced DNA adducts. Toxicol Sci., 95, 376-382. http://dx.doi: 10.1093/toxsci/kfl166.

[35] J.F. Reichard and A. Puga, "Effects of arsenic exposure on DNA methylation and epigenetic gene regulation", Epigenomics. Vol. 2: 2010, pp 87-104. http://dx.doi: 10.2217/epi.09.45.

[36] International Agency for Research on Cancer (IARC), Cobalt and cobalt compounds, Monograms on the evaluation of carcinogenic risks to humans, IARC, Lyon, Vol. 52: 1991, pp 363-472.

[37] M.C. Jung, "Heavy metal contamination of soils and waters in and around the Imcheon Au-Ag Mine, Korea", Applied Geochemistry. Vol. 16: No. 11, 2001, pp. 1369-1375. http://dx.doi:10.1016/S0883-927(01)00040-3.

[38] Abdul Hameed M. J. Al Obaidy and Athmar A. M. Al Mashhadi, "Heavy metal contaminations in urban soil within Baghdad City, Iraq", JEP.Vol. 4: 2013, pp 72-82. http://dx.doi.org/10.4236/jep.2013.41008.

[39] J.M. Deely and J.E. Fergusson, "Heavy metal and organic matter concentration and distributions in dated sediments of a small estuary adjacent to a small urban area", The Science of the Total Environment. Vol. 153: Issue 1-2, 1994, pp 97111. http://dx.doi:10.1016/0048-9697(94)90106-6.

[40] C.S.C. Wong, X. Li and I. Thornton, "Urban environmental geochemistry of trace metals", Environmental Pollution. Vol. 142: 2006, pp. $1-16$ http://dx.doi.org/10.1016/j.envpol.2005.09.004vpol.2005.09. 004 . 